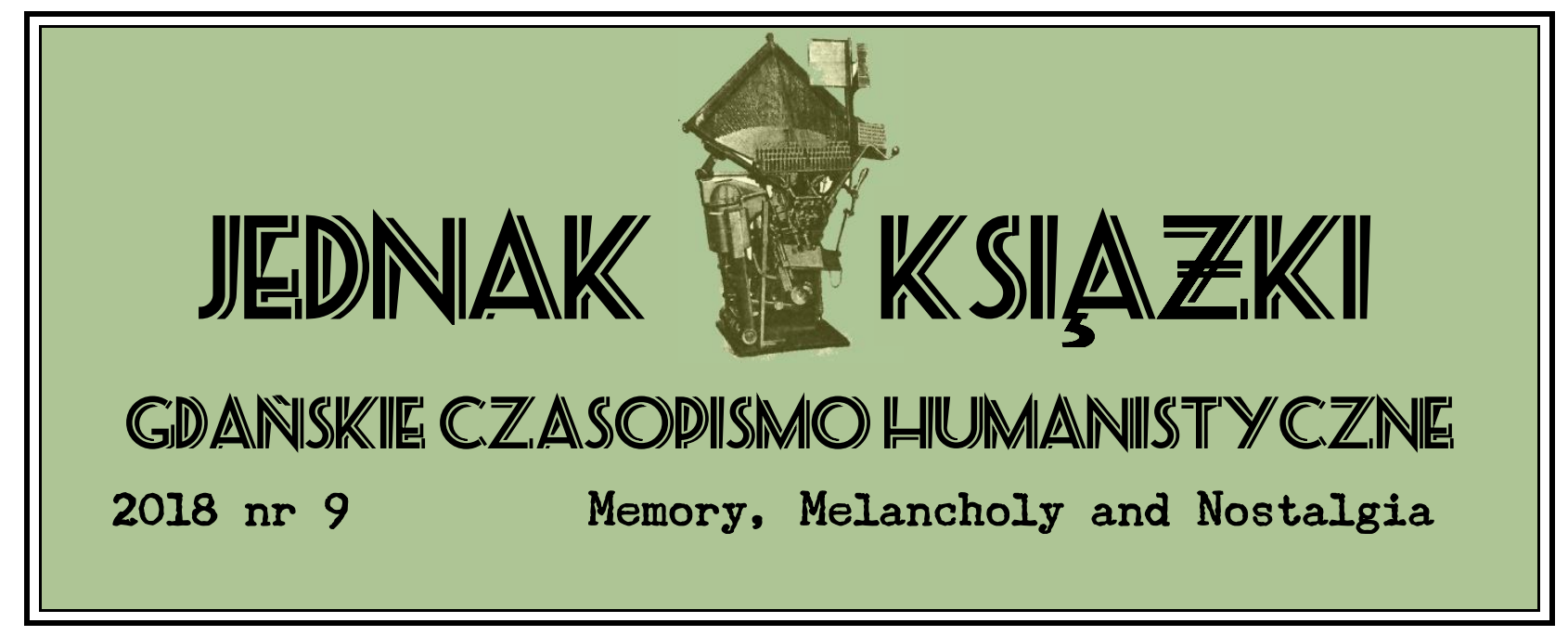

\title{
ESSSAYS
}

https://doi.org/10.26881/jk.2018.9.16

\section{THE MEMORY PLACES AND COLOR: \\ THE METHODS AND PRACTICES OF COLOR USE IN \\ ETHNOGRAPHIC RESEARCH}

\section{HASAN IŞIKLI}

Ghent University (Belgium)

Department of Art, Music and Theater Sciences

\section{Introduction}

olors, which are many times discreet in our daily life, are one of the main elements of
our physical environment. They have certain affect on human's attitude. One reason is
the physical reaction of the body. If an example is given, warm colors reveal sensation of warmness whereas cold ones give a feeling of coolness. Or else, while a combination of dull tones is tended to give calming impression bright tones create vividness. Depending on this, physical interaction between the colors and humans is implemented for functional reasons in daily life. If an example is given red which is a warm color and having the strongest wave-length 
is used to attract the attention whereas a cool one; blue is thought to calm down. This sensation of colors is harnessed for codification by visual communication designers. Especially, the colors of traffic signs have been codified to provide a universal language that would regulate casual life. In the same vein of physical sensation of colors, red is codified culturally to warn about a rule or inform a danger whereas blue would remain the informative one. One should attract the attention and give a reaction immediately other is more open to dialogue. As historian Michel Pastoureau asserts, the red is 'there' to be in the center of attention to not only represent the earthly pleasures but also the danger, whereas blue has become the favorite color of European Union and many institutions because it is the one which is open to dialogue, discreet and ready to be common in the physical environment as we are surrounded by blue sky and blue sea (2005). Nonetheless, again Pastoureau assigns that colors are like a language whose meanings have evolved through the time. The culture which comprises religion, production process of color and the evolution in science has formed the senses of colors. (Pastoureau and Simonnet, 2005) The senses were transmitted again to the language itself and visuality which were nourished by the collective memory; a sort of 'pool' where the information is accumulated and circulated. Naturally the construction of me-mory is provided by the intersection of history, popular mass media and subjects' personal memories; in other words, the oral history. The latter multiplies the senses and events' trans-mission in the society, it may contrast, reflect or show some parallels. (Bilgin, 2011 and 2013).

This article aims to tackle the contribution of color as an instrument of data collection in qualitative research. To study this, I will share my experience of fieldwork among International Izmir Festival participants in which I have studied the concept of awareness of place. Parallel to a half-structured inquiry I implemented colors firstly as a visual to learn how my informants make sense in Izmir, and if possible during International Izmir Festival. Secondly, I attempted to determine how they embed colors' senses to the memory places where they attended to the concerts and faced with the past of the city where cultural traumas like forced migration or big fire are repressed and faded out. Another challenge for this technical study was to develop an interdisciplinary approach between my graphic design background with recent anthropological research. Indeed, although I struggled to manage the subjectivity of fieldwork setting, I could retrieve more practically data thanks to color use. Especially I had more constructive process of dialogue considering my insider positioning as a researcher conducting sometimes interviews with my own relatives and former colleagues from International Izmir Festival. This relatively original method rather than conventional participant observation techniques provided me to jump from 
the blurred "you know what I mean" statements to the clear and concrete ones by my participants in data collection.

\section{- Developing Ethnographic Research Techniques}

\section{A. Organization of the Fieldwork}

The unique difference between office works and fieldwork is that while the researcher is absolutely depended to the documents at the office, in fieldwork there are many dynamics which may turn instantly to advantages as well as constrains. Some items might be counted such as physical conditions, the fieldwork strategies concerning how and when you get in-step out to the community, how you access to the participants, how to not have prejudice or going native or else how to be open without any obtrusive attitude. I was that 'native' one, the contrast of many anthropologists who choose a field area which would be preferably the 'other' to interpret its culture. (Okely, 1996) Indeed as Clifford sarcastically states 'the ethnography would be perfect if (somehow) the ethnographer becomes (when s/he wants) invisible' (1986). My purpose was to combine etics and emics, therefore I couldn't just report what I and the people surrounding me acted and said. My biggest challenge has been not to get in to the community but to provide a clear boundary in the field and to construct a new positioning of ethnographer. I needed to use merely all the advantages of being native but also 'keep an eye awake' by shifting from native to the researcher. Thus, to present myself was also double sided. When I contacted or re-contacted to the International Izmir Festival's participants I was there as they know me and as they didn't know me since I had another role to meet, talk or work with them. Therefore, I focused on the idea 'ethnographer as an instrument' in my fieldwork strategy and searched for an object which would help to assume my new positioning. When a researcher studies his/her own community, the 'blindness' is the first shortcoming of the fieldwork. I might neglect some visuals, objects or jargon finding them common whereas some details might be the tools to dig in or to specify the characteristics of the community. I may suppose that I 'know' who they are and 'what they think' which may become a pitfall. The most difficult part is the second, after being conscious of that the participant is a subject whose identities are fragmented and shifted therefore his/her making sense would be constantly shaped and flow, the other side may still think that I 'know' who they are and 'what they think', thus when I ask a question about the basics such as where the participant goes in daily life and why s/he didn't go to that memory place in daily life the answer seems 'too easy' and the latter may reply 'you know'. But as Pinxten (1997) underscores 
anthropologists cannot 'read' the thoughts of the participants, but they can observe, talk and participate to the same activities to conceive the stratified structure of the meanings of the words and actions. (Geertz, 1973) In that sense I agree with the anthropologists of 'perfect stranger' positioning. (Dikomitis, 2012 and Clifford and Marcus, 1986) When you are supposed to 'know', you may not know what they know and they may not know what you don't know. The parts that I have seen might not be the entireness of the composition, and I may need another instrument to discover other layers putting aside the phrase 'you know'.

If I introduce my fieldwork setting, I conducted a fieldwork among International Izmir Festival's spectators and organizers. I focused on a group who has lived for more than ten years in the metropolitan zone of Izmir. The research group members consisted of high educated, upper-middle class and mostly older than fifty years old people. I also stressed that any participant was expected to participate to International Izmir Festival many times whether regularly or not. The festival itself might be defined as a summer arts festival in which the high culture practice is claimed into the public space. (Dimova, 2012) The program is mainly classical music, but there is a variety of opera, ballet, modern dance, jazz, world music and musical theatre. The characteristics of the festival are the venues. The Celsus Library in Ephesus Antic Site which is $83,8 \mathrm{~km}$. driven by the city center ${ }^{1}$ is the most sustainable concert place. Lastly the festival has given place to the new art center Ahmet Adnan Saygun at the city center. Apart from these stable venues, each year festival team engages to organize a performance in the neglected historical places. In the context of memory studies, I studied the last category, because while the festival attempts to valorize those places as cultural heritage, they also uncover a hidden past that contemporary inhabitants are disconnected. In other words when contemporary inhabitants enter to these memory places the act of organizing a performance in a lien de memoire creates unintentionally an awareness of place process among the participants (including the organizers themselves) While they engage to organize and watch a performance in those place, they interact and contemplate on the past of city which triggers the memory.

Considering the setting of a festival, I entered to the fieldwork mainly with two techniques: in-depth interviews and participant observation. Depending to the conditions, I preferred to implement series of in-depth interviews in the head quarter of the festival organization and the spectators' home and workspaces. That was the most suitable period to implement deep interviews. I aimed to investigate an open questioner so that the participants shall answer what they think and feel, the target was to develop my fieldwork skills and let the participants release themselves.

${ }^{1}$ This distance was calculated in Google Maps from the port of Konak in down town till the entry to the antic site Ephesus. 
First, I started with free recalling technique that is usually done for brainstorming the ideas. I drove my questioner in the spiral form; keeping the core and asking series of question related with that core. However, it might be possible that I could be stuck during the flow of questioner. Or else, the participant could sustain his discourse on some information that $\mathrm{s} /$ he learnt from a book for the sake of giving a smart and elegant impression. It is like in the example of African ethno-historian who wishes to study the cultural identity of a town in Gabon and when he meets with the chief of the town, the chief answers his questions opening a book that another researcher wrote. (Clifford, 1986; 116)

When I reviewed the literature of qualitative methodology, I marked on the idea of the researcher as an instrument. Depending to this the body, the identities and the knowledge of the researcher could be retrieved as an object to harness the fieldwork setting (McCracken, 1988; 1820, Okely, 1996; 28-44, Chereni, 2014; 6-14). I immediately think of myself gathering data during the festival. Running from airport to hotel, then to the venues, meeting with other volunteers and the technical staff of the festival seemed manageable. The unrecorded talking moments, the observation of the staff around me and keeping field notes would be sufficient to collect data. However, if I want to collect data before the festival that I would ask the 'memory' questions about their experience, which instrument would fit to break a potential elitism and the 'noises' between my entity and the participant's one? I risked to hear many times "you know", because I am native and also one of the festival participants. Or else, I would receive the already-known information. My intention was to grasp which salient elements attract the attention of the festival participant, how s/he transmits analogically a possible social interaction among the festival participants with the daily life users of those places, further to see if this color analogy touches both personal and urban memory of the participant and finally the affect of the performance within the place.

\section{B. Color Tablets}

If the colors have been part of collective memory, then any interrogation concerning memory would be implemented by using the colors. I was inspired by the colorist Shigenobu Kobayashi and his book Colorist (1998). Kobayashi describes in his book that when he travels in the cities, he captures three colors that are sovereign in the environment and determines an identity of those cities according to the relations of the color combinations, for instance: 'similarity', 'contrast', 'colorful and soft' and 'calm and hard'. Once the colors are categorized based on his 
observations, he assesses the sense of the combinations such as elegant, casual, fresh and pretty. I paraphrase one of his analyses:

"Hameln, Germany: Fairy Tale - This town is associated with fairy tales and red seems to be a popular color among the townspeople, since women wore vivid red even in summer time. Red geraniums were blooming when I visited, and the red clothes of the flute players were impressive. Red toys could be found in display cases as accents. A combination of dark red and white is used for old houses. Tourists may like the familiar red in this town because of the fairy tale feel it creates" (Kobayashi, 1998; 54).

Similar to this example, Kobayashi constructed the identity of the town not only through what he saw but also what he learned about the local culture. When he writes, "this town is associated with fairy tales" more is revealed through ethnography than a pure color testimony. The combination that he makes is bright, vivid red, saturated green and light brown. According to the pictures in the book, he could say: "it is a vivid city which balances a red combining a hard and dark tone of green and a soft and warm tone of brown in order to create a separation combination." However, apart from the technical terms, his reference to 'fairy tales' is one that he presumably learned from the local people or maybe he saw some ethnic elements in an illustration of children's book. Another theory is that there have been some local festivities or minor events concerning fairy tales during his stay in Hameln. Unfortunately, Kobayashi doesn't explain explicitly why he associates such red tones with 'fairy tales'. The red color might be associated with 'fairytale' in western culture because of the red elements in the tales like red apple (Snow White) and Little Red Riding Hood. The red costumes of the flute players and storytellers may give reference to the history of the town and red geraniums might be significant as well in public space. Therefore, his identification remains less strong than his technique based on his color image scale. Being conscious of this fact, I aimed to give a voice to the festival participants instead of making color analysis of them and the memory places.

Kobayashi is not false in his discourse for the color sensibility of the townspeople that reflect the color identity of their city. Colors may contain the (hi)story of the place. The (hi)story that is constructed on the colors, like the language, interlaces with the meaning of the colors and (hi)story itself (Pastoureau and Simonnet, 2005). Hence, the colors might have the potential to be cultural memory components, too. In the case of Izmir, the dislocation of the indigenous and new settlers prevents this construction and creates a gap between the visual discourse shaped by the global popular culture and Izmir's own past. Precisely, nobody selected the colors of grey, yellow and red, implying the Great Fire of Izmir, because this historical event is not commemorated. While the city's inhabitants changed, the city was detached from its past and rebuilt regarding to the trends of 30's, then 50's and finally from 80's until today. 
To illustrate the technical process of color usage, first I picked the hues demonstrated in Kobayashi's color table $(1998 ; 8-9)$ by comparing it with the PantoneC Color catalogue and Color Index by Jim Krause (2002). After detecting the color values of CMYK2, I designed 120 color squares of $7 \times 7 \mathrm{~cm}$ in computer with Adobe InDesign software. Considering the change of the colors due to the light and texture, I printed them on opaque, standard white paper of $80 \mathrm{mg}$. which was then pasted on white cardboard to create the color tablets. Instead of turning the page, which would give the impression of a test, I preferred that the prospective participant see them randomly spread across the same surface. This more playful approach would enable the participant to select the colors depending on his/her own selective perception of colors.

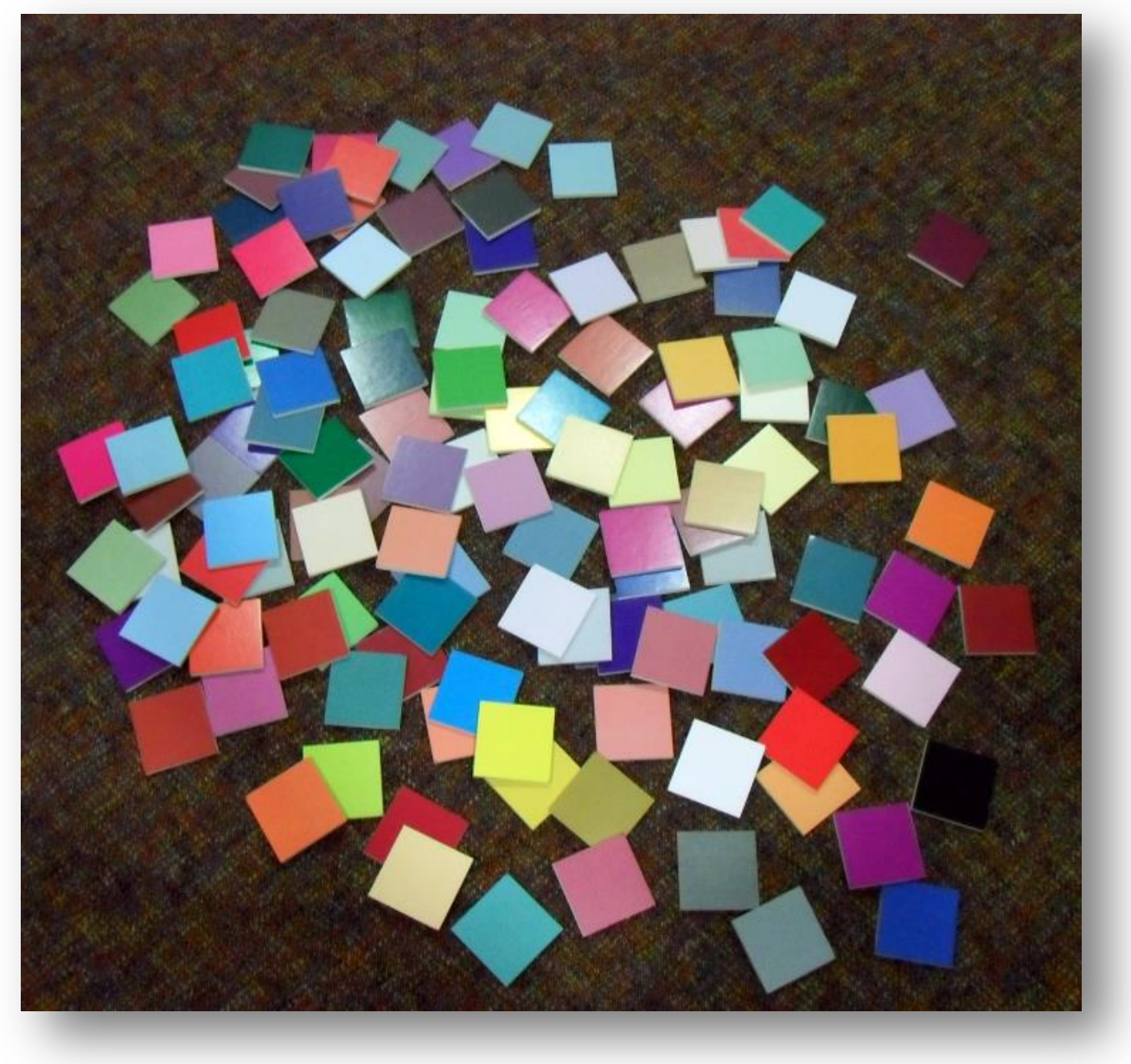

Picture 1: The color tablets spread out to select at random.

\footnotetext{
${ }^{2}$ CMYK: The abbreviation of Cyan, Magenta, Yellow and Black. These are the colors in printing process. Once the image is finalized, it is converted from digital format colors of RGB (Red, Green, blue) to the CMYK values. Either electronic copy machine or a tremendous printing machine, it is necessary to make the configuration of the colors to have an accurate result.
} 
Therefore, after some experiences I decided to evaluate the colors as "prompting object". (Gobo, 2008; 196-197) In this context, I implemented Kobayashi's method as a part of an in-depth interview technique. The colors signified what might transfer the knowledge and also how could be that an image is charged by the visualization and making sense process of 'stories' by the readers. They could be indirect extensions of cultural memory components (mnemonic element). The colors are attached to the culture. Indeed, each community may recall different meaning when looking at the same color. Red is able to be the color of 'fairy tale' in a city from Germany where the sensibility of red might be nourished by the fairy tales like Snow White (red lips, red apple, blood) or a religious reference like blood of Jesus and Vatican. (Pastoureau and Simonnet, 2005).

Moreover, regarding the unobtrusive demand of the participant observation technique in the ethnographic research, I didn't interrupt the flow of their discourse to capture the city's identity relating to its past by asking the participant such questions that 'would reveal the reality'. Consciously, I avoided manipulating my participants by asking leading questions, like the examples below:

Question: “There has been a big fire here, that's why you did select this bright red?"

Question: "You selected bright red. Very interesting. How do you connect your selection with the Great Fire of Izmir?"

I asked to my participants to pick 10 color tablets that represent Izmir for them from a hundred tablets spread out on a table. Then I asked them to see together and alone and what those colors and combination recalled for them. Referring to their home and its neighborhood, some participants picked the colors depicted from their physical environment. After few clumsy inquiries of spreading the tablets, I asked open questions and gave more time to make them express themselves. I realized that color tablets were guiding me to enhance my dialogue with the informants, because I was asking new questions based on their reactions.

If I sustain on memory, the color tablets served the informants to visualize the memory places during the festival. Seemingly not directly referring to any trauma or urban memory but the visualization moment of the informant was illustrating the memory places and their surrounding both in daily life and during the festival. Indeed, their festival experience is a memory and the informant was triggered by the color tablets to remember the memory. According to the results I had many replies of yellow because of summer heat (an analogy between vision and feeling senses related to sunshine) and grey-browns because the buildings and their surroundings were in the variety of dull tones of greys and browns. The preliminary 
questions based on physical environment were gradually shifted to the symbolical narration of the festival experience.

If I give some examples, Emre picked a warm red tone to mention "sokaktaki insanlarm sicakliğ" (the warmness of the people at street) to imply how local people were smiling and sociable. The people at street don't wear red, so it doesn't concern a physical determination, but there is a comparison between the connotation of red as warmth, giving reference to blood, life and human with the humans' behaviors described as 'warm'. When I interviewed Sophie, a European originated informant who has lived in Izmir since 1970s about Abacioğlu Inn in Kemeralt1; the old market neighborhood, she said "When you ask me Kemeralt1, I see immediately a bright red. Because it is the heart of the city. The boat and many bus lines are connected to the square next to Kemeraltı. Kemeraltı is very vivid with such a crowd making shopping but also many people rushing to their work or home. But I also see burgundy; for me it is a noble color. Kemeraltı is also noble because despite of the kitschness (she means the products and window displaying) and destruction [of the old architecture] it is very old and hires something; it is the heart and you may say the spirit of the city as well. It has that wisdom and mysteriousness of burgundy. [The streets] covered by the textiles to make shade. It makes it darker. At night there is nobody and it becomes completely dark."

\begin{tabular}{|c|c|c|c|c|}
\hline \multirow[t]{2}{*}{ INFORMANTS } & \multicolumn{4}{|c|}{ CITED PLACES } \\
\hline & Konak/ Kemeralt1 & Alsancak/ Kordon & $\begin{array}{l}\text { Karşiyaka/ Bostanli/ } \\
\text { Mavişehir }\end{array}$ & Bornova \\
\hline Ahmet (57) & $\begin{array}{l}\text { Black: The ugliest place } \\
\text { that I don't like most }\end{array}$ & $\begin{array}{l}\text { Orange: Cosmopolite; } \\
\text { there is everything }\end{array}$ & $\begin{array}{l}\text { Bright green= } \\
\text { Karşyaka: my childhood, } \\
\text { green of tree/ Bright } \\
\text { red= Bostanll: vibrant, } \\
\text { full of life/ Dull } \\
\text { saturated blue-green= } \\
\text { Mavişehir: it is nice when } \\
\text { the weather is sunny }\end{array}$ & No data \\
\hline Belgin (60) & $\begin{array}{l}\text { Dull saturated purple- } \\
\text { grey: higgledy-piggledy }\end{array}$ & $\begin{array}{l}\text { Deep bright purple: } \\
\text { Cosmopolite and } \\
\text { aggressive }\end{array}$ & $\begin{array}{l}\text { Bright light } \\
\text { blue=Karşıyaka: } \\
\text { Luminous }\end{array}$ & $\begin{array}{l}\text { Dull light green: Calmer } \\
\text { than Konak }\end{array}$ \\
\hline Gizem (36) & $\begin{array}{l}\text { Deep bright brown: } \\
\text { Many buildings with } \\
\text { historical ones }\end{array}$ & $\begin{array}{l}\text { Bright light blue: } \\
\text { Adjusted to the sea }\end{array}$ & $\begin{array}{l}\text { White = Bostanll: When I } \\
\text { leave for outside in the } \\
\text { morning the sea is flat }\end{array}$ & No data \\
\hline Onur (42) & No data & $\begin{array}{l}\text { Light dull yellow- } \\
\text { orange: Because of the } \\
\text { lightning }\end{array}$ & $\begin{array}{l}\text { Bright light pink and } \\
\text { vivid pink= Karşıyaka: } \\
\text { Life is sweet }\end{array}$ & $\begin{array}{l}\text { Bright dark green: More } \\
\text { green, serious and strict } \\
\text { than Alsancak }\end{array}$ \\
\hline Sevim (56) & No data & $\begin{array}{l}\text { Dull strong purple- } \\
\text { blue: A little sea and } \\
\text { mostly concrete }\end{array}$ & $\begin{array}{l}\text { Dull light green= } \\
\text { Karşıyaka: old town, } \\
\text { Çamlık Sokak (Pine tree } \\
\text { Street)/ bright light } \\
\text { blue= Bostanll: Sub- } \\
\text { section of Izmir; lighter/ }\end{array}$ & No data \\
\hline
\end{tabular}




\begin{tabular}{|l|l|l|l|l|}
\hline & & $\begin{array}{l}\text { dull saturated blue= } \\
\text { Mavişehir: blue, seaside } \\
\text { and its name is blue }\end{array}$ \\
\hline Umut (65) & $\begin{array}{l}\text { Bright light yellow- } \\
\text { grey: Marketplace, nested } \\
\text { in the public, tourist, the } \\
\text { grey of between the } \\
\text { streets }\end{array}$ & $\begin{array}{l}\text { Bright light blue: Sea } \\
\text { and sunset }\end{array}$ & No data & $\begin{array}{l}\text { Half-bright green: } \\
\text { Because of its emblem } \\
\text { and it is a green place }\end{array}$ \\
\hline
\end{tabular}

Table 1: The sample of some participants to define Izmir by using the color tablets

Regarding to this finding, I implemented a hybrid technique of color use and free recalling to foster the imagination of the participants. Thanks to their evocations, my informants didn't only describe their physical environment, but also could express the moments of interaction when they circulate in the city. The conversations on these techniques didn't 'tickle their traumas' but instead revealed their conception of Izmir.

In my first fieldwork I hesitated to contact to my informants with the recorder device, camera, notepad and pen. As I was the insider and my informants were one or even two generations older than me, it was challenging to gain their trust and to ask them to share their feelings and thoughts regarding the city's cultural fabric. Despite their modern lifestyle, they were maintaining the traditional way of thinking in regard to age hierarchy and indirect discourse, which potentially caused them to hold back from expressing what they really think and feel at times. In other words, I expected to retrieve more personal account of my informants rather than already-known information transfer. Moreover, the discourse would gain more didactic style reflecting again the social hierarchy. I was ready to utilize myself as an instrument, specifically an instrument that I would deliberately consider my own background during the interviews. Therefore, the color tablets have been a bridge between me and my informants. I would feel at ease reclining to my graphic designer past and the responses and reactions of the informants would be turned at first level around of color tablets playing, then the stereotypes that they evocate and pass finally their own personal experiences in Izmir especially during International Izmir Festival.

If I unfold more about color tablets being a bridge between my entity and my informants, they have become gradually the motivation objects of an individual that one tells about his physical environment and its connotations. One may illustrate its home, the neighborhood, business area and the places that $\mathrm{s} /$ he circulates in Izmir. One of the informants, Umut joked that the color tablets were 'intelligence test' while Nicole resembled them 'just like my 
appointment with the painter last time'. I discovered that this method has got a playful effect on the informants and decreased first the moments of stumbling when one says 'you know' and I feel anxious to gain a flow in the conversation. Second, there was less reluctant approach of 'I accepted this interview out of politeness because you are a relative of my friend' or the anxiety of 'I must say something very smart to prove my intellectual capacity'. Many times the ethnographers face the difficulty of striking a balance between asking the questions clearly without undermining the notions and distorting the discourse according to the education level of the research group members. In my case, my informants were highly educated adults, thus I could ask more abstract questions. Yet at the beginning of the fieldwork I had some difficulties to understand their emotions and self-expressions at the first meetings. For the sake of conserving their social status, they would offer more informative and general data than a personal statement. McCracken (1988) claims that the visuals help to focus on the questions and reveal information that wouldn't be reached only by open questions. Indeed, I noticed later that the participants would skip some questions saying 'you know' or they would jump to an irrelevant topic when there was a lack of visual material. In a similar way, I had used the photos taken by myself to support the color tablets, with the aim to trigger the memory of my participants. However, the photos were more figurative and 'real' images created different obstacles between the flow of recalling moments and my retrieving questions. The participants were criticizing the pictures from an artistic angle. What it is called 'noise' in the photography were disturbing them, such as the cars passing by the building and avenue and the fact that I asked about their experiences with other urban objects, like the advertisement boards, street lamps and the shop signs dividing and complicating the composition of the printed photo. Despite of my informants' critiques, I believe that these 'noises' were also part of their contemporary life. I construed their negative reactions as an envy to calmer space. Once, after looking the pictures of an avenue with many cars, street lights with the façade of an old bank at background Umut recalled the concert in roman Agora and said how he was disturbed by the sound of cars, especially trucks driving uphill next to the concert.

\section{Conclusion}

As a result of this experience, I developed more prompting question techniques based on the experiences of in-depth interviews. I asked to my informants to identify Izmir with the color tablets. My intention was to access further their making sense process of memory places during International Izmir Festival. Although I didn't grasp any direct data concerning the cultural 
traumas because they were not commemorated and not visible anymore in their lives, the color tablets have been useful methodologically for my ethnography. They became mnemonic objects to remember their experiences in memory places and further playful objects that they were interacted and prompted to speak more about their personal account than citing a formal discourse. In addition to this, color identification of the memory places embedded into their neighborhood has visualized the stereotypes of Izmir city which could be retreated as a visual communication design project. While the informants were asked to identify Izmir with the colors they departed by the main axes and their living hood, because the colors triggered an image of the city formed by their memories. Regarding from the replies, I extracted that while some replies referred to physical environment others were implying more symbolical meanings.

Colors have certainly a relation with the memory. This relation needs to be investigated more in an interdisciplinary perspective. However, my observations concerning the reactions and self-reflexivity indicate that color use remains as a practical tool. It becomes a prompting object of in-depth interview in which the prospective informant is engaged playfully. The playfulness of color tablets session motivates to talk with an insider beyond of 'you know' answer. Moreover, it reduces the anxiety of the informant to 'say important things' and the ethnographer to be stuck in open questioner. Both the researcher and the informant may feel at ease, hence the researcher has an opportunity to create more fluent dialogue with the prospective participant.

\section{ACKNOWLEDGEMENTS}

All articles published in the issue are the revised texts based on lectures delivered at the $4^{\text {th }}$ International Interdisciplinary Memory Conference in Gdansk "Memory, Melancholy and Nostalgia” (17-18 Semptember, 2015). 


\section{SUMMARY}

\section{The Memory Places and Color: The Methods and Practices of Color Use in Ethnographic Research}

Nowadays art festivals engage more to organize their events in unusual places. Either for the sake of city branding or a pure cultural memory action, a performance might be set in a forgotten memory place. The place which is distinguished sharply by a comfortable concert hall becomes one of the actors of the event and the participant questions a past that $\mathrm{s} /$ he hasn't been strongly connected. Thus, the individual is not only aroused by the performance itself and the information in the booklets but also physical environment has an affect. This article aims to tackle the contribution of color as an instrument of data collection in qualitative research. By using color tablets inspired by the colorist Kobayashi the colors are tested firstly as a visual to learn how they make sense in Izmir during International Izmir Festival. Secondly, they are questioned how the participants embed colors' senses to the memory places where they attended to the concerts. The research process indicates that the experience of a concert might not be visually powerful enough to associate memory places with the colors. However, the technique of color tablets becomes prompting object which support the dialogue construction between the fieldworker and informant. Thus, as an instrument for evocation and conversation color tablets become interactive objects for remembering of the festival experience and it mediates the social roles of the informants and the fieldworker.

\section{KEYWORDS}

Color tablets, Kobayashi, ethnographic interview, memory place, International Izmir Festival

\section{BIBLIOGRAPHY}

Behar, Ruth. 1996. The Vulnerable Observer. In: The Vulnerable Observer. 1-33. Boston: Beacon Press.

Bilgin, Nuri. 2013. Tarih ve Kolektif Bellek Istanbul: Bağlam Press

Bilgin, Nuri. 2011. Sosyal Düşüncede Kent Kimliği' (City Identity in Social Thought) İdealkent Journal Vol. 3: 20-47 
Chereni, Admire. 2014. Positionality and Collaboration During Fieldwork: Insights From Research With Co-Nationals Living Abroad in Forum: Qualitative Research, Vol 15, No. 3

Clifford, James and Marcus, George E., ed. 1986. Writing Culture: The Poetics and Politics of Ethnography. University of California Press

Clifford, James. 1986. On Ethnographic Allegory. In: Writing Culture: The Poetics and Politics of Ethnography, 98-121. University of California Press

Dikomitis, Lisa. 2012. Cyprus and Its Places of Desire: Cultures of Displacement among Greek and Turkish Cypriot Refugees. London: I.B. Taurus

Dimova Rozita. 2012. "The Ohrid Festival and Political Performativity in the Contemporary Republic of Macedonia”. Journal of Balkan and Near Eastern Studies Vol. 14 (2): 229-244.

Geertz Clifford. 1973. Thick Description: Toward an Interpretive Theory of Culture. In: The Interpretation of Culture. New York: Basic Books

Gibson David. 2009. The Wayfinding Handbook, Information Design for Public Places. New York: Princeton Architectural Press

Gobo, Giampietro. 2008. Doing Ethnography. L.A.: Sage Publications

Göregenli, Melek. 2010. Çevre Psikolojisi: Insan Mekan Illiskkileri. Istanbul: Istanbul Bilgi University Press

Grafik Tasarım (graphic design magazine), Volume 28. 2009/01, "Bilgilendirme Tasarımı"

(Orientation, Wayfinding and Sign System) / Information Design). 68-95

Halbwachs, Maurice. 1950. The Collective Memory. Harper \& Row

Kobayashi, Shigenobou. 1998. Colorist: A Practical Handbook for Personal and Professional Use. Tokyo: Kodansha International Ltd.

Krause, Jim. 2002. Colour Index: Over 1100 Colour Combinations, CMYK and RGB Formulas, for Print and Web Media. United Kingdom: HOW Design Books.

McCracken, Grant. 1988. The Long Interview. Newbury Park, London, New Delhi: Sage Publications

Okely Judith. 1996. Own or Other Culture. London and New York: Routledge

Pastoureau, Michel and Simonnet, Dominique. 2005. Le Petit Livre des Couleurs. Paris: Editions du Panama

Pinxten, Rik. 1997. When the Day Breaks: Essays in Anthropology and Philosophy. Frankfurt am Main: Peter Lang 